\title{
A STUDY OF STUDENTS’ SPEAKING SKILL THROUGH VLOG
}

\author{
Amelia Sri Rahayu ${ }^{1}$ Vina Nurviyani ${ }^{2}$ \\ Suryakancana University \\ amelia.rahayu09@gmail.com¹ vinanurviyani19@gmail.com²
}

\begin{abstract}
Vlog is one of the popular technology or social media which can be used as an instructional. According to Parker and Preiffer (2005) that vlog is currents video blog are essentially text blogs with externally linked videos for each entry. This research examined a study of students' speaking skill through vlog to tenth grade of vocational high school. this research aimed to find out the implementation of learning speaking through vlog, to examine the strengths and the weaknesses of learning speaking through vlog, to investigate the responses given by students toward of learning speaking through vlog. The research was conducted in SMK Al-Fathonah Cianjur. The participant of this research was the students in tenth grade. This research used qualitative research: a study case. The research used non-participants classroom observation, interview, and questionnaire. The classroom observations were conducted three meetings. The interview and questionnaire were conducted after doing observation. Interview involved four students and questionnaire involved all students (20 students). The results showed that vlog can help them in learning speaking and foster their speaking skill. Further, the students were very enthusiastic in learning speaking through vlog. Vlog is suitable for learning speaking and narrative text material. Learning speaking through vlog is more flexible. However, students should have adequate facilities to learn speaking through vlog. Students gave positive responses of implementation learning speaking through vlog is fun, interesting and make students motivated to improve their speaking skills. Based on the findings, vlog can only be implemented in learning speaking at the intermediate and upper level such as junior high school, senior high school or vocational high school, and university.
\end{abstract}

Keywords: vlog, speaking, and speaking skill

\section{INTRODUCTION}

Many students are not interested or motivated in learning speaking because students learn speaking by listening explanations and using white boards and markers, so students are not active and creative in learning speaking. The students in this research are gen $\mathrm{Z}$. In common with millennial, generation $\mathrm{Z}$ is comfortable with technologies that are recent for older generations, and gen $\mathrm{Z}$ has grown up in the current environment of ubiquitous mobile communications. Therefore, teachers now should follow the development of the latest technology and the internet in order that teachers understand what makes students interested. 
According to Thomas (cited in Rakhmania and Kusumaningrum, 2009), doing the online videos offers learners the opportunity to practice their language skills anywhere and with little prior preparation, which keeps them involved in the process. Nowadays there are various instructional media based technology such as Cartoon Story Maker, Sway, Powtoon, Quizlet, social media, blog, online videos such as vlog, and many more that make students easier to understand the lesson and make students interest in learning.

Many speaking research using instructional media based technology, but speaking research using video is rare. Video blog (Vlog) is one of latest internet technology that arises in 2016 and still exist until now. However, the study of speaking skill through vlog is still rare. Thus, the research of students' speaking skill through vlog is significant to do.

Based on the background the researcher conducts the research aim to answer research questions. In this research there are three questions as follow:

1. How is the implementation of learning speaking by using vlog as an instructional media?

2. What are the strengths and the weaknesses of implementation in learning speaking through vlog?

3. What are the students' responses to the learning speaking through vlog?

\section{THEORETICAL FRAMEWORK}

\section{The use of Vlog as Media in Learning Speaking}

According to Nunan (cited from Astuti, 2013) teaching speaking means teaching students to produce the English speech sounds and sounds patterns, using word and sentences, intonation patterns, and rhythm of the second language, selecting appropriate word and sentences according to the proper social, setting, audience, situation and subject matter, to organize their thoughts in a meaningful and logical sequence, using language as a mean of expressing values and judgments, using the language quickly and confidently with few unnatural pauses which is called as fluency. Teaching speaking means teaching communication and everything about speaking to students in detail, from the easiest to the most difficult.

Many teachers use instructional media in learning process to achieve learning goals and to stimulate students' motivation in learning, especially in learning speaking. Gagne (1987) defines that media are various components in learners' environment which support the learners learn. Instructional media is used to support and help teachers and students learning 
process, especially for students it can facilitate them in understanding learning. Teachers should choose the appropriate instructional media for teaching in learning, because the instructional media that used should affect the effectiveness of learning. It is supported by Brown (1973) explaining that instructional media are utilized in learning activities will affect the effectiveness of learning.

There are so many instructional media are used in teaching started from the simplest to the most complex ones, from non-technology and internet connection, up to with the need of the technology and internet connection. Scanlan (2003) states that instructional media encompasses all the materials and physical means an instructor and teacher might use to implement instruction and facilitate learners' achievement of instructional objectives. According to Vernon (1996, cited in Ruis, Muhyidin, Waluyo, 2009), there are six kinds of instructional media: (1) Drawing or teacher mode drawings, (2) Still pictures, (3) Audio recording. (4) Motion picture and TV, (5) Real object, (6) Programmed and computerassisted instruction. Vlog is included in motion picture and TV category. Vlog is a video recording presented in a moving image from live action. Objects may be in normal motion and edited for abbreviating or high lighting. It can be silent or having audio.

Vlog offers comfortable and personal sites for people to practice the target languages (Rakhmanina and Kusumaningrum, 2017). Since vlogging is mostly oral, speaking is the major component. It is supported by Christian (2009), he explains that personal vlog comprises a head-on close-up shot and the vlogger looks at the camera to discuss the details about their life and recent happenings in their life.

Vlog has some advantages, such as vlog help students to improve their English speaking skill, students do better on storytelling, expressing ideas, and others, students could also be involved in vlog as project assignment (Rakhmanina and Kusumaningrum, 2017). This vlog project assignment fosters their personal communication skill on foreign language. Vlog in learning speaking have some weaknesses for some students, especially low motivated students. They are difficult to elaborate their ideas, thoughts and feeling, they tend to be p'assive and usually get the knowledge only from their teacher, they lack of awareness, courage and lazy to join the learning activity (Rakhmanina and Kusumaningrum, 2017).

Inadequate facilities also become the weakness of learning speaking by using vlog (Rakhmanina and Kusumaningrum, 2017). Students must have computer or smartphone to create and upload vlog. To upload a vlog it requires a good internet connection.

The content of students' vlogs in this research is narrative text made by the students themselves. It is supposed by Anderson and Anderson (2003a) explain that a narrative is a 
text that tells a story and, in doing so, entertains the audience. From explanation above, narrative text describes an experience, which its social function is to amuse or entertain the audience with the story.

\section{METHOD}

This study applied qualitative design. Creswell (2014:2) states, Qualitative research is an approach for exploring and understanding the meaning individuals or group ascribe to a social or human problem. This qualitative research by focusing on case study is considered suitable for finding the answers to the research questions of this research. According to Yin (1984, p. 23) states that the case study research method is an empirical inquiry that investigated a contemporary phenomenon within its real life context, when the boundaries between phenomenon and context are not clearly evident, and in which multiple source of evidence are used.

There were several reasons in choosing qualitative research especially a case study in this research. First, this study focused on the study of a case that is the process of learning speaking by using vlog. Second, this research also focused on the issue of particular phenomena, which has internal validity and contextual understanding, rather that generalizability and comparability.

\section{Participants}

The participants of this research were students in vocational high school student of $\mathrm{X}$ TKJ B grade. They were selected based on their ability in English and their background, where all of them were using English as a foreign language in this country.

There were several reasons of choosing students of X TKJ B (Teknik Komputer Jaringan) grade as the participants of the research. First, the students were ready to involve in this research, in the term of time and readiness. Second, they were less interested in learning speaking and tend to be afraid when they practiced speaking in class so they were difficult to foster their speaking skills. Furthermore, in this research, the totals of participants were 20 students studying in similar classroom. They are 15 females and 5 males in X TKJ B class.

\section{Instruments}

To obtain the data, the researcher used three instruments namely classroom observations, interview, and questionnaire. Each instrument is explained below.

\section{Classroom Observations}


Classroom observation is one of instruments in this research. According to Hancock et. al (2009), observation is a technique that can be used when the data cannot be collected through other means, or those collected through other means are limited value or are difficult to validate. Classroom observation was conducted to get the information of the real situation in this research. The researcher can observe directly in learning speaking through classroom observation.

The observer acted as non-participant and involved in teaching and learning process. The researcher observed teaching and learning activities in class. The researcher observed students as the participants.

\section{Interview}

Interview is data collecting implemented by giving questions to the respondent based on the subject of the research. According to Kumar (2005) Interview was conducted for the several data collection methods exist in qualitative research. The researcher posed interviews to students as the participants to collect the by data using audio recorder to anticipate something missing or forgotten in transferring the data and help the researcher as interviewer in gaining data more detailed during interview.

Referring to explanation above, There were 15 questions posed in interview related to the research questions (see appendix II). Questions number 1-5 were asked to participants to answer the first research questions about how the process of speaking learning by using vlog. Questions number 6-10 were asked to answer the second research questions. It was about the strength and the weaknesses of implementation in learning speaking through vlog. Then, questions number 11-15 were asked to answer the third research questions about students' responses in speaking learning through vlog.

The researchers interviewed four students. Students were two the most interesting and two other were in learning speaking by using vlog. The questions were delivered in Indonesia to get clear information. The interview was conducted at the end of the lesson in the last meeting on Wednesday, April 11, 2018.

\section{Questionnaire}

Questionnaire was another data collection in this research. According to Arikunto (1996, p. 128) state that "questionnaire is some written question used to get the information from respondent about their personality or anything that she/he knows". This research used open-ended questionnaire to get general description about learning speaking through vlog. Arikunto (1996, p.128) stated that open-ended questionnaire (unstructured questionnaire) 
gives the respondents freedom to reveal their opinions and attitude. The researcher gave 15 questions to participants in Indonesia language, to answers the all research questions.

\section{Data Analysis}

The data analysis conducted to answer all research questions. The data obtained from classroom observations, interview, and questionnaire were analyzed, categorized, and interpreted into three themes based on the research questions.

Classroom observations were analyzed to answer all research questions. The researcher used observation field note about everything happened during the learning activities, particularly speaking class. There were several steps to analysis the data from observation: First, researcher recorded all activities that occur during the learning activities in the note book. Second, researcher transcribed all activities that occur during the learning activities in detail in the form of a table. Third, researcher makes some comments from the learning activities transcribed in a table. Fourth, researcher analyzed and interpreted the data taken from the field note. Fifth, researcher concluded the data from field notes. The steps of taking notes are effective to answer all research questions. To reach the findings to answer the research questions.

Furthermore, interview were analyzed and interpreted to find out all of the research questions. There were four students who were interviewed. There were several steps to analysis the data from interview: First, researcher conducted interviews with four students as participants and recorded interviews by using a smartphone recorder. Second, researcher transferred audio recordings to a computer to make listening and transcript data easier. Third, researcher listens to the audio carefully, then transcribe the audio file. Fourth, researcher made interview codification in the form of a table. Fifth, researcher analyzed and interpreted the data taken from the interview. Sixth, researcher concluded the data of interview to find out the findings of this research.

Meanwhile, questionnaire was analyzed to answer all of the research questions. There were several steps to analysis the data from questionnaire. First, the researcher shared the questionnaire to each student. Second, students answered and submited questionnaire. Third, researcher transcribed the entire of questionnaire. Fourth, researcher made questionnaire codification in the form of a table. Fifth, researcher analyzed and interpreted the data taken from questionnaire. Sixth, researcher concluded the data from questionnaire to reach the findings of this research.

\section{FINDINGS AND DISCUSSION}


This chapter discusses the data obtained from classroom observations, interview and questionnaire, the data used to answer all of the research questions. The first question investigated the implementation of learning speaking by using vlog, the second was the strengths and weaknesses of implementation of in learning speaking through vlog, and then the third the students' responses in learning speaking through vlog.

\section{The Implementation Vlog in Speaking Learning}

The implementation vlog in speaking learning ran well. It can be seen from the result of classroom observation data, interview data, and questionnaire data that all that implementation in leaning speaking through vlog was suitable instructional media for students because the implementing vlog help students in learning speaking and foster their speaking skill.

Classroom observations showed that students enthusiastic during learning process and students tell their stories about memorable experience expressively and confidently in their vlog. Interview and questionnaire also describe the implementing vlog help students in learning speaking and foster their speaking skill.

\section{The Strengths and the Weaknesses of Vlog in Learning Speaking}

There are five the strengths of implementations in learning speaking through vlog, such as the students can speaking practice anywhere, the students can see the weakness or strength of their speaking skills by looking at their vlog, the students more confident and courage in speaking, the students can more concentrate when speaking practice, the teacher and the students can utilize technology to learning, especially for students. The implementations in learning speaking through vlog, has two weaknesses, such as the students have to through several steps to create a good vlog, the students should have adequate facilities like smartphones, laptops or computer, and good internet connection.

The classroom observations data showed three strengths and a weakness of implementation in learning speaking through vlog. The interview and questionnaire data showed five strengths and three weaknesses.

\section{The Students' Responses to The Learning Speaking through Vlog}

The students' responses to the learning speaking through vlog were positive, none of the negative students' responses in learning speaking through vlog. It can be seen from the students' attitude during the learning process.

Classroom observation showed most of students seemed very enthusiastic when the teacher explained how to create a vlog. Vlog makes students interested in learning speaking 
because vlog is new instructional media for teacher and students. Data from interview and questionnaire showed various positive students' responses toward learning speaking through vlog.

\section{CONCLUSIONS}

This research reported the result of leaning speaking through vlog. The aims of the research were to find out the implementation of learning speaking through vlog, to examine the strengths and the weaknesses of learning speaking through vlog, to investigate the responses given by students toward of learning speaking through vlog. Based on findings and discussion in the previous chapter, the researcher found implementation of learning speaking through vlog was suitable instructional media. Vlog has several strengths and weaknesses of in learning speaking through vlog. The strengths of vlog in learning speaking more than the weaknesses. Students gave positive responses toward learning speaking through vlog, such as students very enthusiastic when the teacher explained how to create a vlog, vlog makes students interested in learning speaking because vlog is new instructional media for teacher and students, learning speaking though vlog is fun and not boring as usual, students' are motivated to improve their speaking skills, vlog recommended for further learning speaking.

\section{REFERENCES}

Astuti, A. F. (2016). Improving students' speaking skill through storytelling. A Paper. Unpublished. Cianjur : Suryakancana University.

Arikunto,. S. (1996). Prosedur Penelitian: Suatu Pendekatan Praktek.

Brown, H. D. (1973). Audio-visual instruction: Technology, media, and methods. New York: McGraw-Hill.

Creswell,. J. W. (2014). Research Design: Qualitative, Quantitative, and Mix Method Approaches. University of Nebraska-Lincon: SAGE publication, Inc.

Christian, A. J. (2009). Real vlogs: the rules and meanings of online personal videos. First Monday.

David, Nunan. (1991) Research Methods in Language Learning. New York: Cambridge University Press.

Gagné, R.M. (1987). Instructional Technology: Foundation. Hillsdale, NJ: Lawrence Erlbaum Associated

Hancock, B., Ocleford, E., \& Windridge, K. (2009). An Introduction in Qualitative Research. NHS: University of Nottingham.

Kumar. (2011). Research Methodology. New Delhi : SAGE. 
Parker. \& Pfeiffer. (2005). Vlogging: A Survey of Videoblogging Technology on The Web. https://www.semanticscholar.org/paper/Vlogging\%3A-A-survey-of-videobloggingtechnology, accessed on September 8, 2017.

Rakhmanina, Lisa. \& Kusumaningrum, Dian. (2017). The Effectiveness Of Video Blogging In Teaching Speaking Viewed From Students' Learning Motivation. Proceedings of the Fifth International Seminar on English Language and Teaching. Accessed on December 10,2017

Ruis. Muhyidin. Waluyo. (2009). Instructional Media. Jakarta : Ministry of National Education.

Scanlan, Craigh. L. (2003) Instructional Media: Selection and Use. http://www.uab.edu/instructional media/cdm/media.htm, accessed on June 1, 2018.

Yin, R. K. (1984). Case Study Research: Design and Method. Newburry Park, CA: SAGE. https://www.ishcool.utexas.edu/ ssoy/usesusers/1391d1b.htm, accessed on 21 April, 2018. 